\title{
化粧品の触覚体験に着目した触感計測法の開発
}

\section{Development of Tactile Experience Based Evaluation Method of Tactile Sensations of Cosmetics}

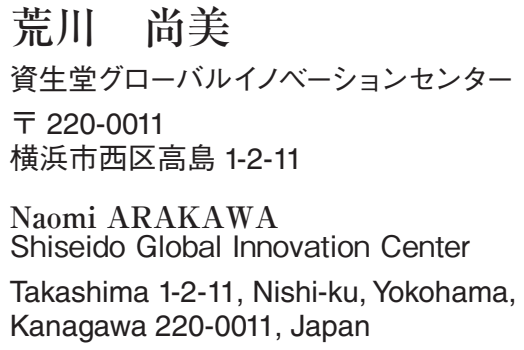

Naomi ARAKAWA

Shiseido Global Innovation Center

Takashima 1-2-11, Nishi-ku, Yokohama, Kanagawa 220-0011, Japan
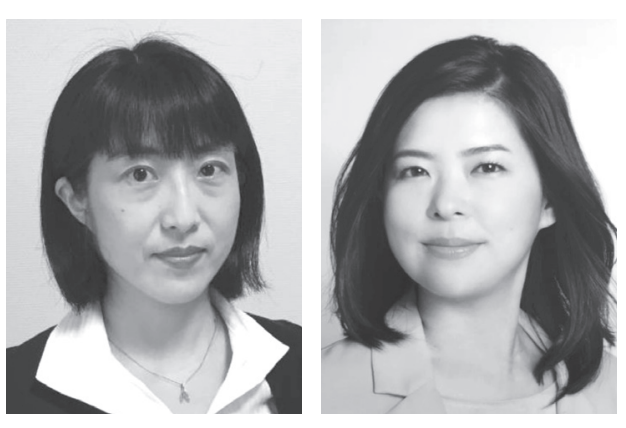

柿澤 みのり

資生堂グローバルイノベーションセンター

T 220-0011

横浜市西区高島 1-2-11

Minori KAKIZAWA

Shiseido Global Innovation Center

Takashima 1-2-11, Nishi-ku, Yokohama,

Kanagawa 220-0011, Japan

論文要旨：生活者は化粧品を選好する際，五感の中でも特に嗅覚・視覚・触覚でその商品が嗜好に合うか を判断している。そのため, 生活者が求める嗅覚・視覚・触覚的要素を開発者が理解して製品開発すること が重要である。しかし, 生活者が求める触覚体験（触感）は主に言葉で表現されるため, 生活者が表現する 触感の物性を具体的に理解するのは難しい。そこで我々は, 化粧の触覚体験を考慮した触センサを開発し, 生活者が表現する触感を触センサで数值化を行っている。本稿では，指で皮膚を押した時に感じる柔軟感を 指の替わりとなって定量化する皮膚柔軟感センサと, 化粧用具を把持している際の指の接触力から感じる基 剤の感触を推定するウエアラブル接触力センサの開発事例を紹介する。

\begin{abstract}
When consumers select cosmetics, they judge whether the product match their preferences using their five senses, especially smell, vision and touch. Thus, it is very important to understand the olfactory, visual and tactile factors that the consumer desires in order to develop optimal products. As the tactile experience that consumers desire is expressed verbally, it is not trivial to understand the specific underlying tactile sensations. Therefore, we have developed original tactile sensors for tactile experiences of cosmetics and, using these sensors, we have quantified the consumers' tactile sensations. In this paper, I'll introduce two of these sensors: a softness sensor system that can measure perceived skin softness when fingers push skin, and a wearable contact force sensor that uses the force of grasping cosmetics to estimate the tactile sensation of cosmetics.
\end{abstract}

Key words: cosmetics, haptics, tactile feeling, sensor, skin

\section{1 はじめに}

生活者は化粧品を選好する際, 五感の中でも特に嗅覚, 視覚, 触覚を通じてその商品が自身の嗜好に合うかを判 断している。さらに，この良い感覚体験は化粧品購入の 判断基準だけでなく，情緒的な価值をもたらす。「化粧 と心」の関りに関する研究が半世紀以上にわたって行わ れており ${ }^{1)}$ ，化粧は心を彩り，そして心を動かす働きが あることが知られている。最近では，スキンケアにおい て好みのテクスチャを適切な方法で塗布されることによ る触覚体験が気持ちに好影響が与えられることが知られ

連絡者：荒川 尚美

E-mail : naomi.arakawa1@shiseido.com
ている ${ }^{2)}$ 。そのため, 化粧品開発者は生活者が好む感覚 体験を知り，モノづくりに活かすことが重要である。

生活者の好む感覚体験を知る際，アンケートやインタ ビューなど言葉を介して回答を得る方法が多く用いられ る。開発者はその言葉から具体的な物性を理解し, その 物性をもたらす商品を開発しなければならない。開発者 はその言葉から具体的な物性を理解できるであろうか? 私たちは, 生活雑貨や香水, 食品の香りに接することで, さまざまな香りとそれを表す言葉に接する機会が多い。 色や質感においては, 化粧品だけでなく, 文房具や衣類 などに接することで，私たちは色の種類とそれを表す言 葉に接する機会が多い。さらには, 色においては, 見本 のように微細な色の違いを言葉や物性で定義がされてい 
る。つまり，嗅覚や視覚の体験は，特定の物性を表す言 葉に共通認識がある。一方, 触覚体験は色見本のような 定義がない。例えば, 柔軟感は,「柔らかい」や「ハリ感」 のような言葉で表現されるが, 柔らかさの程度の違いを 表現する言葉がない。つまり，開発者が言葉を介して生 活者が好む触覚体験の物性の種類や度合いを知ることが 難しい。そのため, 言葉で表現される触覚体験を物性で 評価することが望まれている。

そこで，筆者らは触覚体験時に感じている触刺激を定 量化する触センサを開発した。触覚体験を言葉で取得す ると同時に触センサにより定量化することで，触覚体験 を具体的な物性で理解できる。本稿では，指の替わりと なって指で皮膚を押した時に感じる柔軟感を定量化する 皮膚柔軟感センサと，指先で化粧用具を把持している際 の接触力から基剤の触覚体験を推定するウエアラブル接 触力七ンサの 2 つの触センサの開発事例を紹介する。

\section{2 皮膚柔軟感を定量するセンサシステムの開発}

加齢や環境により皮膚は変化する。生活者は自身の皮 膚を見たり触れたりすることで皮膚状態を確認してい る。皮膚の「柔らかさ」や「ハリ感」などの柔軟感も例 外ではない。皮膚の柔軟性を力学物性で定量化する評価 法が活発に開発されている ${ }^{3)}$ 。さらに, 訓練された専門 評価者が皮膚を触って触感をスコア化する官能評価と, 機器による皮膚の力学物性の測定值との相関を調べるこ とにより, 触感の定量化を目指している研究が知られて いる ${ }^{4)}$ 。しかしながら, 生活者が皮膚に触れて感じる柔 軟感において，感覚量と力学物性との因果関係を知るた めの知覚心理学的検討による知見がそしい。そのため, 相関関係を調べるだけでは，ヒトの柔軟感知覚に必要は ないが計算上相関がある物性が選ばれる可能性がある。 そこで, 生活者が感じている皮膚柔軟感を定量化するセ ンサシステムの構築を目指し, 心理学的アプローチと工 学的アプローチの 2 つフェーズに分けて研究を行った

(Fig. 1)。

第 1 フェーズの心理学的アプローチについて述べる。

\section{Superficial layer}

(Five levels)

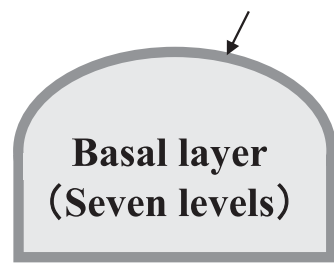

Fig. 2 Schematic of bilayer skin tactile models.

皮膚は力学物性が異なる角層, 表皮, 真皮, 皮下組織の 各層が積み重なっている。そこで先行研究 ${ }^{5)}$ を参考に して, 「皮膚の柔軟感は全体の力学物性と表層の力学物 性が影響する」という仮説を立てた。この仮説を検証す るため, 内層とその内層を取り囲む薄い膜できた表層の 2 層の構造を持つウレタン製ドーム状の触感サンプル 35 種（Fig. 2）を用い, 触感評価実験を行った。触感サン プルの内層は体積を一定にし，ポリウレタン基剤の重合 剂配合量に応じて架橋重合度を変えることで, 内層の力 学物性を 7 水準（19-25, 1 刻み）に変化させた。表層は 内層よりも硬い物性を持つウレタン基剤を用い, 膜の厚 さ 5 水準 $(7,15,30,45,60 \mu \mathrm{m})$ により表層の力学 物性に変化させた。被験者（日本人男女計 40 名）に内 層の架橋重合度 7 水準と表層の膜厚 5 水準の組み合わせ で計 35 種の触感サンプルの「柔らかさ」と「ハリ感」 を評価させた触感評価実験の結果を Fig. 3 に示す。横軸 は内層の架橋重合度, 縦軸は表層の膜厚を示す。眓中の セルの中で, 被験者が該当する触感サンプルを触り 60\%以上の人が「柔らかさ」及び「ハリ感」を感じた触 感サンプルにそれぞれ印をつけた。「柔らかさ」の評価 では架橋重合度が 20 以下の触感サンプルで「柔らかさ」 を感じたと回答する被験者が多かった。一方，「ハリ感」 の評価では膜厚が $7 \mu \mathrm{m}$ で架橋重合度が 22 の時, 膜厚 が $15 \mu \mathrm{m}$ 以上の時は架橋重合度が 23 の時に「ハリ感」 を感じたと回答する被験者が多かった。つまり，皮膚の 柔軟感を感じるために必要な物性は, 体積の大部分を占 める内層と表層の力学特性のバランスが重要であること

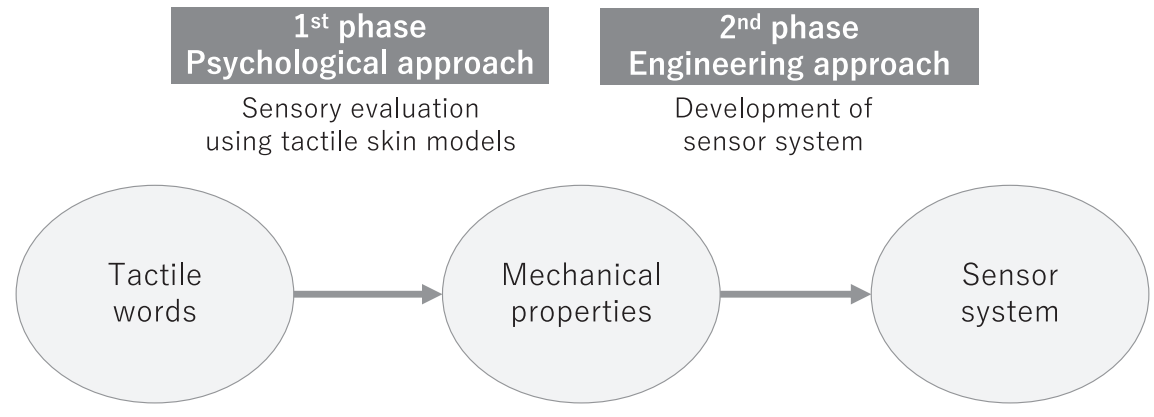

Fig. 1 Overview of development of skin softness sensor system. 


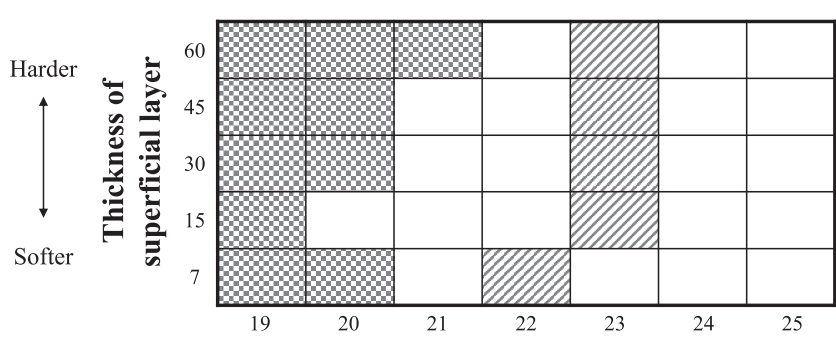

Perceived softness

Perceived firmness

Degree of cross-polymerization of urethane resin in the basal layer

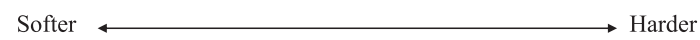

Fig. 3 Results of sensory evaluations of skin tactile models.

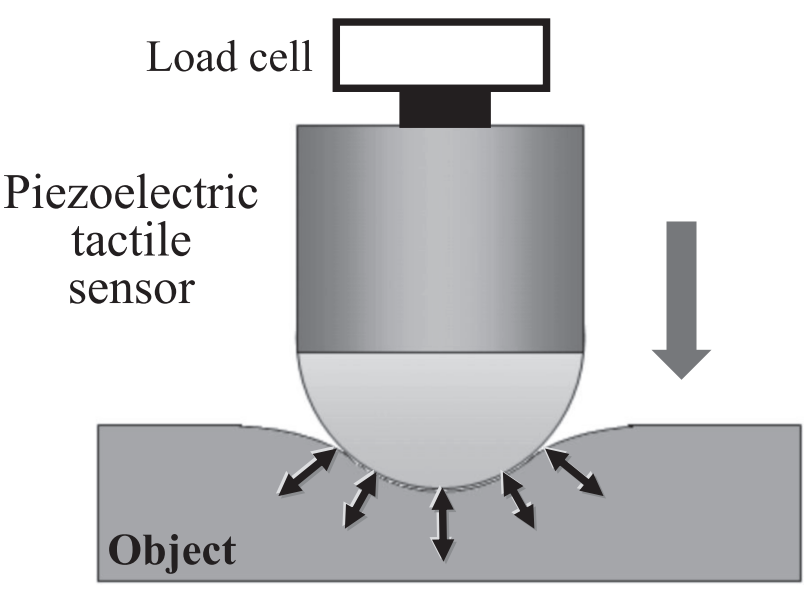

Fig. 4 Schematic of the Skin softness sensor.

がわかった。

次に第 2 フェーズの工学的アプローチについて述べ る。第 1 フェーズで特定した力学物性を測定できる皮膚 柔軟感センサ ${ }^{6.7}$ を開発した。皮膚柔軟感センサの構成 図を Fig. 4 に示す。皮膚柔軟感センサはロードセルとピ エゾ振動子の 2 つセンサを有する。接触子が対象物に 押下した時のロードセルが計測する接触力で内層の力学 特性を評価した。また同時に，ピエゾ振動子による共振 周波数の変化量で表層の力学特性を評価した。共振状態 にある接触子が対象物に接触することで，対象物の音響 インピーダンスに依存した共振周波数は変化する。例え ば，対象物が柔らかいほど接触後の共振周波数が小さく なること ${ }^{8,9)}$ が知られており，この原理を皮膚測定に応 用した。

第 1 フェーズで用いた触感サンプル 35 種を皮膚柔軟 感センサで測定した結果を Fig. 5 に示す。横軸は内層の 力学特性を示す架橋重合度, 縦軸は皮膚柔軟感センサに より測定された接触力（Fig. 5 (a)）もしくは周波数変 化量（Fig. 5 (b)）である。接触力は内層の架橋重合度 とともに増加したが, 膜厚による接触力の変化は少な かった。一方, 周波数変化量は内層の架橋重合度の変化 よりも表層の膜厚に伴う変化の方が大きかった。つまり，
開発した皮膚柔軟感センサで「柔らかさ」や「ハリ感」 が知覚される際に影響する物性である「内層の力学物性」 と「表層の力学物性」が同時に測定可能であることが示 唆された。

開発後は, 皮膚柔軟感システムで測定できる 2 つ皮 膚物性から皮膚の柔軟感の定量に活用されている ${ }^{10)}$ 。

\section{3 ウエアラブル接触カセンサの開発}

生活者が化粧品を施す時は，基剤を直接指で塗布した り, 容器を指で把持したりする。その時の触覚体験は指 で感じる物性からもたらされる。例えば, 指で感じる抵 抗力により基剤のなめらかさを感じ, 指で感じる接触力 で皮膚の柔らかさを感じる。これらの物性は指の指紋部 が直接, 対象物に接することで検知している。以前の技 術では，グローブ型のセンサを手にはめることにより自 然な動作で指の接触力を測定できるものはあったが，い ずれも指紋部を覆う必要があった。そのため,「指の指 紋部を妨げることなく」「自然な動作」で，指で検知し ている物性を定量化することが求められていた。

そこで，物性の中でも特に興味のあった接触力に着目 し，指の指紋部を覆わず自然な動作中の接触力をリアル タイムで測定できるウエアラブル接触力センサ ${ }^{11}{ }^{12}$ をを 開発した。センサの構成と測定原理を Fig. 6 に示す。セ ンサはウエアラブル可能な小型かつ軽量の特徵を有して いる。コの字型をしており，指の爪側から指両端を挟み 込むように装着する。センサは 2 つの歪ゲージと 3 軸加 速度センサを内蔵している。指が対象物に接触した時に 指が水平方向に膨らむときの力を歪ゲージが測定する。 この指の膨らみ方には個人差がある。そのため, あらか じめ接触力と歪ゲージの值を校正しておくことで, 触動 作中の歪ゲージの值から接触力を推定できる。また, 加 速度センサは，指の動きに関する測定を行っている。

ウエアラブル接触力センサを用いてスティックロ紅を塗 布している時の使用感触の定量的評価事例を紹介する ${ }^{13)}$ 。 スティックロ紅はスティックを握り, 基剤を唇にあて, 
(a)

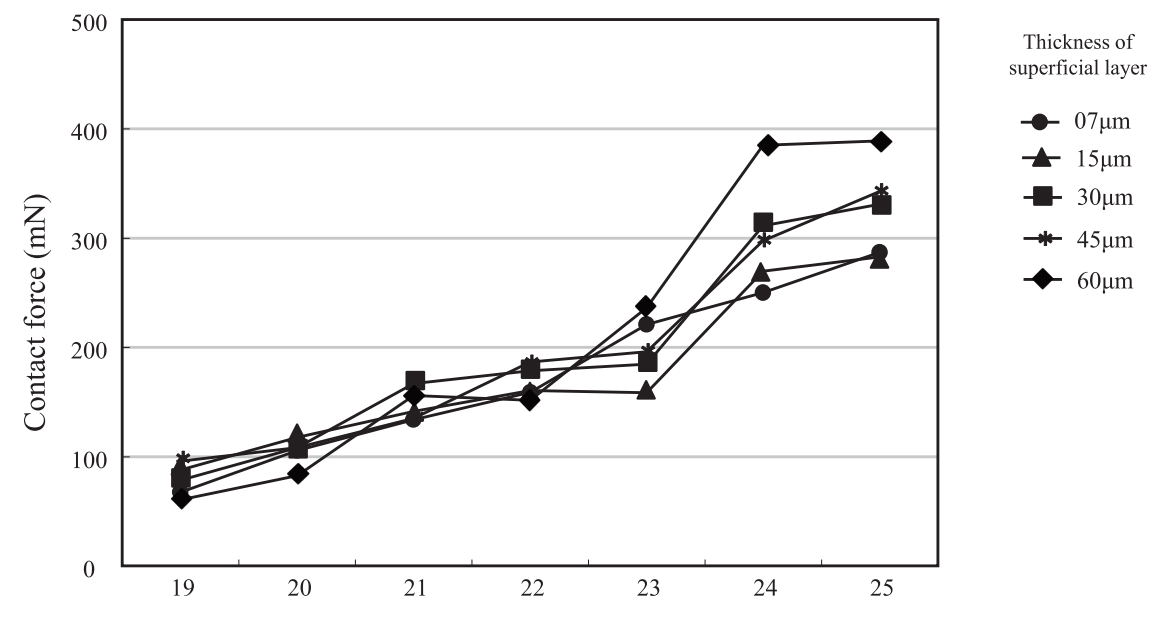

Degree of cross-polymerization of urethane resin in the basal layer

(b)

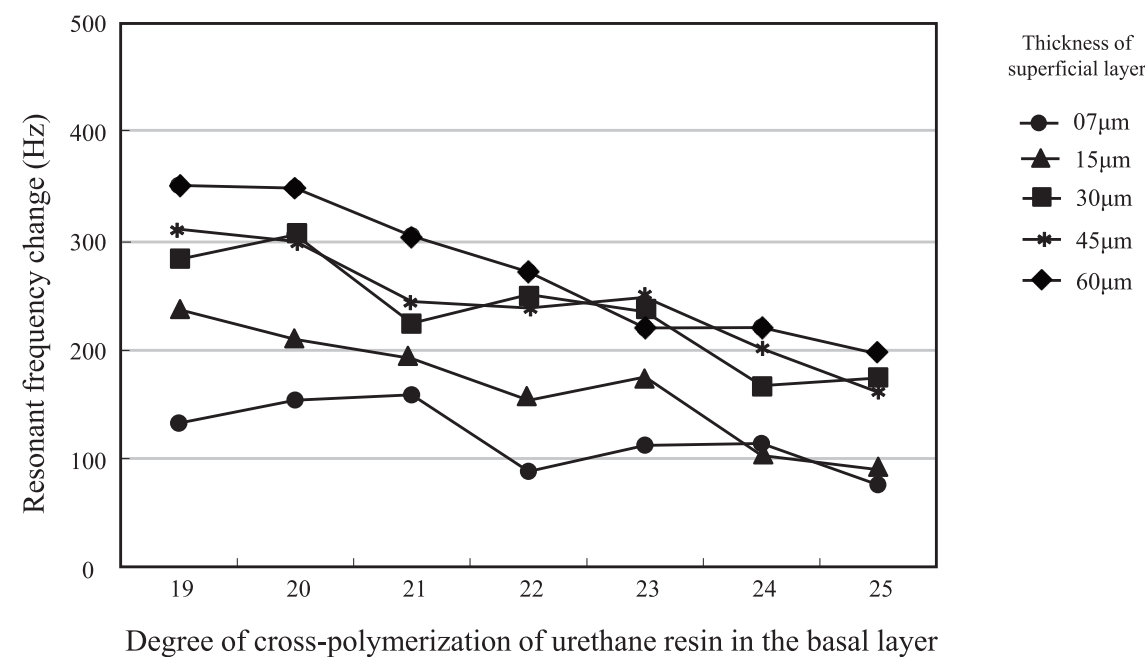

Fig. 5 Measurement data of skin tactile models acquired with load cell (a) and the piezoelectric sensor (b).

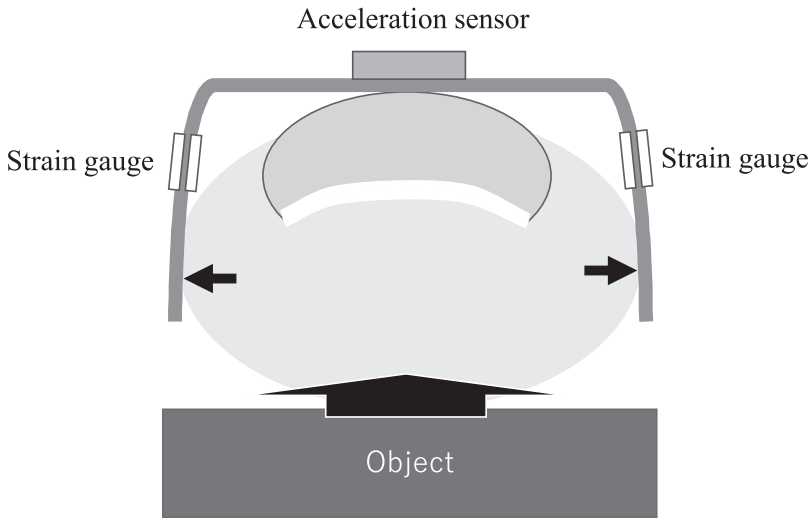

Fig. 6 Measurement principle of wearable contact force sensor based on fingerpad deformation.

唇上に基剤を押し滑らせるように塗布する。同じ容器形 状であれば，口紅基剤の硬度や摩擦などの特徵は，塗布 時にスティックを握っている指の接触力に影響があるの ではないかと考えた。そこで, ウエアラブル接触力セン
サを示指に装着し，唇の絵が印刷された紙上に硬度の異 なる 8 種の口紅それぞれを 5 往復塗布した時の指の接触 力を計測した結果を Fig. 7 に示す。硬度の低い口紅を把 持している指の方が硬度の高い口紅を把持している指に 比べ接触力が小さかった。また，実使用条件でも計測を 行った。なめらかさをより感じる硬度の低い口紅基剤を 塗布した時の方が, 塗布時の把持力が小さかった。この ように，指が指紋部を覆うことなく自然な動作で指が検 知した接触力を計測できる装置を開発し, 化粧時の触覚 体験を定量的に評価できることが示唆された。

開発後は，スキンケアやメーキャップなどの化粧動作 時の触覚体験の定量に活用されている ${ }^{12)}$ 。

\section{4 おわりに}

本稿では，化粧品の嗜好に影響する重要な感覚体験の 一つである触覚体験に着目し, その触覚体験を定量化す る 2 つ触センサの開発事例を紹介した。同様の触セン 


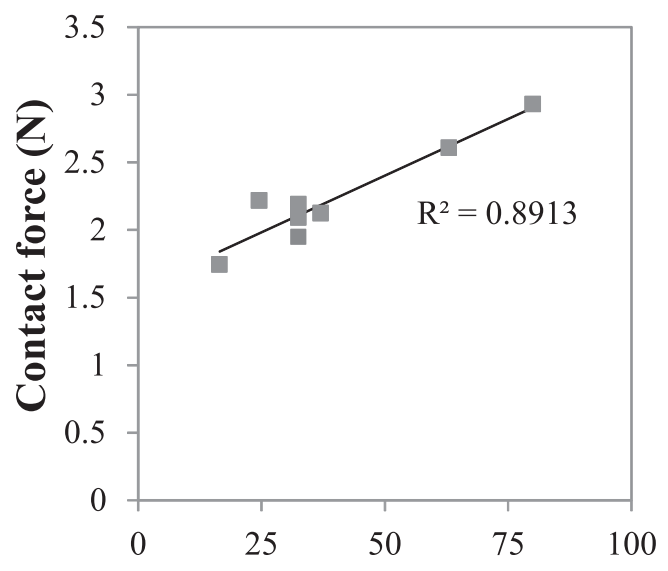

Hardness of lipstick base (gf)

Fig. 7 Relationship between hardness of lipstick base and contact force during applying lipsticks on the sheet.

サの開発は, 日々進化している。風間らは皮膚柔軟感を確 かめる動作を模擬したセンサを開発し，押し込み量と反力 の時系列データの特徴量と柔軟感との関係を示した ${ }^{14)}$ 。齋 藤らは, 皮膚になぞり動作で生じる振動を計測できるセ ンサを開発し, 振動の特徴量としっとり感やなめらかさ との関係を示した ${ }^{15)}$ 。生活者に良い触覚体験をもたら す化粧品開発を行うためにも, 触覚体験の定量評価が必 要である。今後も, 言葉で表現される生活者の触覚体験 を定量化する技術のさらなる発展を期待したい。

\section{文 献}

1）資生堂ビューティーサイエンス研究所, 化粧心理学, フレグランスジャーナル社 (1993). (Shiseido Beauty Science Laboratory, The psychology of cosmetic behavior, Fragrance Journal Ltd. (1993). )

2）渡辺智子, 荒川尚美, 岡崎龍太, 池田華子, 第 22 回日 本感性工学会大会·要旨集, 2D01-05-01 (2020). (Watanabe, T. et al. The 22nd Annual Meeting of Japan Society of Kansei Engineering, Abstract 2D01-0501 (2020). )
3）高橋元次, フレグランスジャーナル, 36, 39-48（2008）. (Takahashi, M. Fragrance Journal 36, 39-48 (2008).)

4) 川畑真理絵, 藪崎次郎, 山川弓香, 大場愛, 粧技誌, 46, 205-218 (2012). (Kawabata, M. et al. J. Soc. Cosmet. Chem. Jpn. 46, 205-218 (2012).)

5）白土寛和, 野々村美宗, 前野隆司, 日本機械学会論文 集 (C 編)，73，541 (2007). (Shirato, H. et al. Trans. Jpn. Soc. Mech. Eng. Ser. C 73, 541 (2007). )

6) Nakatani, M.; Fukuda, T.; Sasamoto, H.; Arakawa, N.; Otaka, H.; Kawasoe, T.; Omata, S. Int. J. Cosmet. Sci. 35, 84 (2013).

7) Nakatani, M.; Fukuda, T.; Arakawa, N.; Kawasoe, T.: Omata, S. Skin Res. Technol. 19, e332-e338 (2018).

8) Omata, S.; Terunuma, Y. Sens Actuators A 35, 9(1992).

9) Omata, S.; Murayama, Y.; Constantinou, C.E. Sens Actuators A 112, 278-285 (2004).

10）荒川尚美, 仲谷正史, 福田達, 柿澤みのり, 笹本裕美, 川副智行, 尾股定夫, 第 69 回 SCCJ 研究討論会・講演 要旨集, 14-15 (2011). (Arakawa, N. et al. The 69th SCCJ Research Symposium, Abstract 14-15 (2011).)

11) Nakatani, M.; Kawasoe, T.; Shiojima, K.; Kinoshita, S.; Koketsu, K.; Wada, J.; Brown, J. IEEE World Haptics Conference 2011, 21-24 (2011).

12) Kakizawa, M.; Nakatani, M.; Kawasoe, T.; Shiojima, K.; Kinoshita S.; Koketsu, K.; Wada, J. IFSCC Mag. 16, 101-105 (2013).

13）柿澤みのり, 荒川尚美, 長島愛, 齋藤直輝, 川副智行, 口紅の基剤物性が塗布動作における指の握りや塗布時 間に与える影響, 第 75 回 SCCJ 研究討論会・講演要旨 集, 24-25 (2014). (Kakizawa, M. et al. The 75th SCCJ Research Symposium, Abstract 24-25 (2014). )

14）風間泰規，荒川尚美，齋藤直輝，岡本正吾，第 15 回日 本感性工学会春季大会・要旨集, 3B-01 (2020)。（Kazama, Y. et al. The 15th Spring Annual Meeting of Japan Society of Kansei Engineering, Abstract 3B-01 (2020). )

15）齋藤直輝，松森孝平，風間泰規，荒川尚美，岡本正吾， ロボティクス・メカトロニクス講演会, 2A1-P16（2020）. (Saito, N. et al. The Robotics and Mechatronics Conference 2020, 2A1-P16 (2020). ) 